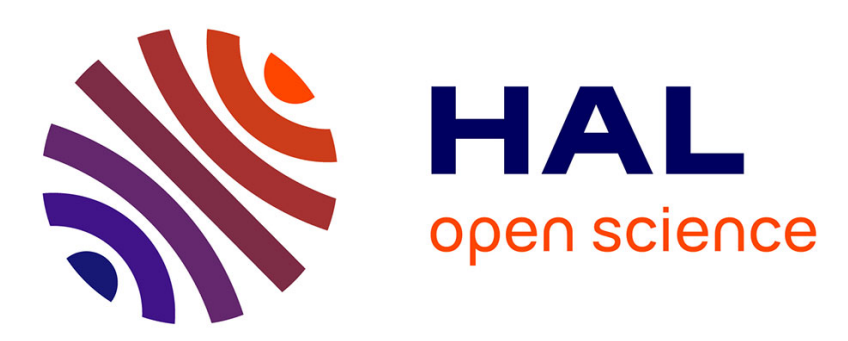

\title{
2-D optical quantification of particle reworking activities in marine surface sediments
}

Franck Gilbert, Stefan Hulth, Niklas Strömberg, Katja Ringdahl, Jean-Christophe Poggiale

\section{- To cite this version:}

Franck Gilbert, Stefan Hulth, Niklas Strömberg, Katja Ringdahl, Jean-Christophe Poggiale. 2-D optical quantification of particle reworking activities in marine surface sediments. Journal of Experimental Marine Biology and Ecology, 2003, vol. 285-286, pp. 251-263. 10.1016/S0022-0981(02)00531-2 . hal00761763

\section{HAL Id: hal-00761763 \\ https://hal.science/hal-00761763}

Submitted on 15 Mar 2013

HAL is a multi-disciplinary open access archive for the deposit and dissemination of scientific research documents, whether they are published or not. The documents may come from teaching and research institutions in France or abroad, or from public or private research centers.
L'archive ouverte pluridisciplinaire HAL, est destinée au dépôt et à la diffusion de documents scientifiques de niveau recherche, publiés ou non, émanant des établissements d'enseignement et de recherche français ou étrangers, des laboratoires publics ou privés. 


\title{
2-D optical quantification of particle reworking activities in marine surface sediments
}

\author{
Franck Gilbert ${ }^{\mathrm{a}, \mathrm{b}, *}$, Stefan Hulth ${ }^{\mathrm{a}}$, Niklas Strömberg ${ }^{\mathrm{a}}$, \\ Katja Ringdahl ${ }^{\mathrm{c}}$, Jean-Christophe Poggiale ${ }^{\mathrm{b}}$ \\ a Analytical and Marine Chemistry, Göteborg University, SE-412 96 Göteborg, Sweden \\ ${ }^{\mathrm{b}}$ Laboratoire d'Océanographie et de Biogéochimie, UMR CNRS 6535, Campus de Luminy, \\ Case 901, F-13288 Marseille Cedex 09, France \\ ${ }^{\mathrm{c}}$ Department of Marine Ecology, Göteborg University, Kristineberg Marine Research Station, \\ SE-450 34 Fiskebäckskil, Sweden
}

\begin{abstract}
Particle and solute transport by faunal activities may significantly influence rates and pathways of organic matter mineralization during early diagenesis in surface sediments. One of the most frequently utilized techniques to quantify benthic biological reworking activities involves the calculation of a biodiffusion coefficient $\left(D_{\mathrm{b}}\right)$ estimated from model predictions of 1-D tracer distribution patterns. This technique is labor-intensive and time-demanding. Furthermore, it is normally used for measurements over several days and averages overall transport mechanisms from 3-D to 1-D on a cm scale. In the frame of this work, we developed a new technique based on the nondestructive screening of fluorescent particles (luminophores) using optical discrimination and CCD camera detection of fluorescence (2-D). At a site characterized by a dense population of the brittle star Amphiura filiformis and a high biodiffusion coefficient (obtained from 1-D distributions; $D_{\mathrm{b}}=35.5 \pm 3.7 \mathrm{~cm}^{-2}$ year $^{-1} ; n=3$ ), the optical reworking coefficient (ORC), estimated from the 2-D luminophore distribution patterns, was calculated (ORC $\left.=27.4 \pm 9.1 \overline{\Delta Q} \mathrm{~cm}^{-2} \mathrm{~h}^{-1} ; n=24\right)$. A nondestructive 2-D approach to quantify particle reworking may provide a powerful and complementary tool to further understand particle transport by the benthic fauna in surface sediments. The optical technique for 2-D detection of luminophores is relatively fast and easy to
\end{abstract}

* Corresponding author. Laboratoire d'Océanographie et de Biogéochimie, UMR CNRS 6535, Campus de Luminy, Case 901, F-13288 Marseille Cedex 09, France. Tel.: +33-4-91-82-91-04; fax: +33-4-91-82-65-48.

E-mail address: gilbert@com.univ-mrs.fr (F. Gilbert). 
perform, with the ability to detect small scale $(\mathrm{mm})$ particle movements on a time resolution of minutes or less.

Keywords: Amphiura filiformis; Luminophores; Sediment reworking; Two-dimensional optical quantification

\section{Introduction}

In bioturbated sediments, particles are subject to various uni- or omnidirectional displacements due to reworking activities of benthic infauna (Rhoads, 1974; Aller, 1982; Berkenbusch and Ashley, 1999; Franç ois et al., 2001). Biologically mediated transport of organic and inorganic particles across redox boundaries may considerably affect rates and pathways of organic matter mineralization during early diagenesis in surface sediments (Aller, 1994; Gilbert et al., 1996; Hulthe et al., 1998; Sun et al., 1999). Due to the strong influence on sedimentary transformation reactions and transport processes, sediment reworking is a key component in the understanding of overall sediment biogeochemistry, and quantification of biologically induced particle transport is a vital parameter for large- and small-scale diagenetic models (Soetaert et al., 1996; Boudreau, 1997).

Generally, biological particle reworking is evaluated by diffusion models (Berner, $1980)$ and quantified by the associated biodiffusion coefficient $\left(D_{\mathrm{b}}\right)$ predicted from the model. This coefficient of sediment reworking is normally verified by experimental manipulations such as additions of fluorescent particles (Gérino et al., 1998), or direct quantification of the vertical distribution patterns of more or less conservative tracer elements, e.g. ${ }^{210} \mathrm{~Pb},{ }^{234}$ Thorium, Chl. $a$ (e.g., Gérino et al., 1998; Berg et al., 2001). From a natural 3-D displacement of luminescent particles or particle adsorbed tracers in the sediment, the distribution of tracer is projected in horizontal layers with a resulting 1-D repartition. Generally, the sediment has been sectioned in cm-thick layers and the experiment lasts at least a few days.

Recent developments of planar optodes (or plate fluorosensors) have allowed direct quantification of 2-D solute distributions of $\mathrm{O}_{2}$ and $\mathrm{pH}$ (Glud et al., 1996, 2001; Hulth et al., 2002). Main principles of these optical plate sensors is to screen an illuminated fluorescent solute specific sensor foil in direct contact with the sediment for high spatial $(50-100 \mu \mathrm{m})$ and temporal (less than minute) resolution 2-D imaging of solute distributions patterns. Intensity of fluorescence is directly related to solute concentration.

The overall objective of this study was to develop a fast, nondestructive technique for direct determination of 2-D sediment reworking rates with high temporal and spatial resolution. To fulfill these requirements, we made use of a similar optical setup as for the 2-D pH sensor (Hulth et al., 2002). Quantification of sediment reworking rates with this novel optical approach was applied at a site characterized by intense reworking activity mainly caused by a high density population of Amphiura filiformis (up to more than 3500 ind. $\mathrm{m}^{-2}$; Rosenberg, 1995). This brittle star switches between 
suspension and deposit feeding depending on hydrodynamic conditions in the bottom water and organic matter availability (Buchanan, 1964), and uses its arms in the sediment to adjust its position and to direct its movement (Rosenberg et al., 1997). A . filiformis is known to be a highly active sediment reworker (Rosenberg et al., 1997), as recently confirmed also by time-lapse sediment profile imagery (Solan and Kennedy, 2002).

\section{Materials and methods}

\subsection{Sites and sediment sampling}

Stations in the Gullmars Fjord and the Skagerrak area were visited in August 1999 and May 2001 (Fig. 1; Table 1). In 1999, sediment cores (i.d. $10 \mathrm{~cm}, 30 \mathrm{~cm}$ height) were sampled at each of the five stations (S1-S5) using a multiple corer (Barnett et al., 1984). During the 2001 cruise, only the Deep Trench station in the Skagerrak was studied (S5; Table 1). Sediment subsamples were taken from an Olausson box corer $(50 \times 50 \mathrm{~cm})$ using transparent Plexiglas rectangular cores $(4 \mathrm{~cm}$ side, $30 \mathrm{~cm}$ height).

\subsection{Sediment reworking}

In 1999, the sediment cores were incubated at in situ temperature under a water flow system allowing three complete turnovers of water each day in each core. In order to quantify the sediment reworking activity in the sediments, the overlying water was removed and fluorescent luminophores $(4 \mathrm{~g} ; 80-150 \mu \mathrm{m}$ diameter) were deposited at the sediment surface (Gérino, 1990). Then, the water flow system was reactivated. After 9 days of incubation, the sediment cores were sectioned and each layer $(1 \mathrm{~cm}$ thick) was sieved through a $250-\mu \mathrm{m}$ mesh to separate macrofauna (preserved in $4 \%$ buffered formaldehyde for individual identification) and particles. Sediments were then dried and homogenized. Sediment subsamples were taken for luminophore counting under UV light (Mahaut and Graf, 1987).

The diffusive-like transport of luminophores demonstrated by the tracer repartition profiles in the different sediments allowed us to describe mathematically this bio-mediated transport process as a diffusive one. Then, for each core, a biodiffusion coefficient $\left(D_{\mathrm{b}}\right)$ was calculated using the Cochran model (1985).

In 2001, the sediment cores were incubated at in situ temperature under a water flow system. Fluorescent luminophores ( $2 \mathrm{~g} ; 80-150 \mu \mathrm{m}$ diameter) were deposited at the sediment surface. Cores were then precisely positioned at various time intervals in front of the optical system and pictures of core faces were taken. The optical system used in this study was based on the system already used by Hulth et al. (2002) for 2-D quantification of $\mathrm{pH}$. Excitation light $(300 \mathrm{~W}$ Xe UV/VIS arc lamp; band pass $510 \mathrm{~nm}$ excitation filter) was transferred to the sample by a liquid light guide. Light emitted by the luminophores was collected, via an emission Hi Pass $460 \mathrm{~nm}$ filter (absorbs every wavelength up to $460 \mathrm{~nm}$ ), by an 8-bit COHU 4910 integrating monochrome CCD camera (chip resolution $753 \times 582$ pixels). The theoretical individual pixel resolution for 


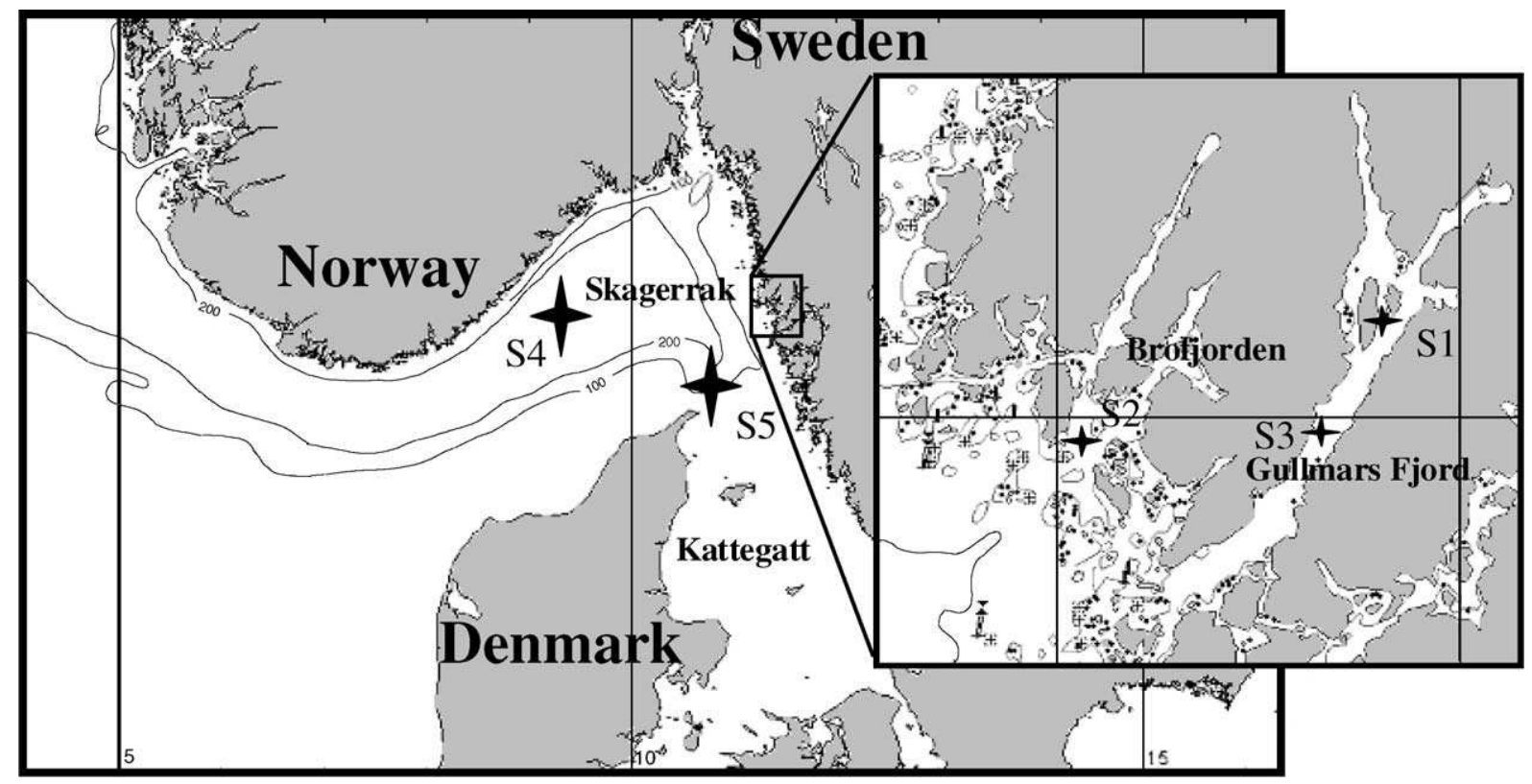

Fig. 1. Map showing the stations visited during the August 1999 and May 2001 (only S5) cruises. 
Table 1

Sediment reworking parameters, biodiffusion coefficient $\left(D_{\mathrm{b}}\right)$ and burying depth, measured during the 1999 cruise with the "classical luminophore method"

\begin{tabular}{llllll}
\hline Station & & & \multicolumn{2}{l}{ Sediment reworking } \\
\cline { 1 - 2 } \cline { 5 - 6 } Name & Location & Water depth $(\mathrm{m})$ & & $D_{\mathrm{b}}\left(\mathrm{cm}^{2}\right.$ year $\left.{ }^{-1}\right)$ & Burying depth $(\mathrm{cm})$ \\
\hline S1 & The Gullmars Fjord & 75 & $16.0 \pm 0.1$ & $6.5 \pm 0.5$ \\
S2 & The Gullmars Fjord & 95 & $13.9 \pm 0.1$ & $4.5 \pm 0.5$ \\
S3 & The Gullmars Fjord & 118 & $12.2 \pm 0.8$ & $5.0 \pm 0$ \\
S4 & Skagerrak, the Norwegian Trench & 680 & $5.4 \pm 0.6$ & $3.0 \pm 0$ \\
S5 & Skagerrak, the Deep Trench & 95 & $35.5 \pm 3.7$ & $6.7 \pm 0.5$ \\
\hline
\end{tabular}

the COHU camera as set up was $8.5 \times 8.5 \mu \mathrm{m}$. NIKON standard single-lens reflex (SLR) lenses were used to optimize spatial resolution and size of the image. Effective image resolution was $75 \times 75 \mu \mathrm{m}$ at the distance employed between core and camera $(20-40$ $\mathrm{cm})$. The data acquisition software InCytIm2y was controlled by a Windows-based PII-400 MHz computer.

Images obtained with InCytIm2y software were thresholded and binarized in order to get "luminophore pixels" coded with 1 and "sediment pixels" coded with 0 . Each image was thus associated to a matrix of 0 and 1 . The temporal evolution between two images (e.g. M1 and M2) was then globally quantified by the difference of the matrices corresponding to the different times. This process led to a new matrix (called $\mathbf{M}$ ) of 0 , 1 and -1 values containing a global information of the movement of luminophores with time (Fig. 2). The value 0 was related to the pixels that did not change. The value 1 was related to the pixels that moved from "sediment" to "luminophore" state, and inversely for the value -1 .

A reworking coefficient was then constructed to summarize the total reworking information contained in the matrix $\mathbf{M}$ (Fig. 2). The sum of all the numbers in the $\mathbf{M}$ matrix quantifies the total variation of amount of luminophores. A positive result means that the number of values equal to 1 is larger than the number of values equal to -1 . As the sum was image size dependent, we proceeded then as follows:

- for a fixed number $k$, all the cells of size $k \times k$ pixels contained in the image were considered,

- a matrix was associated to each cell in the same way as for the complete image,

- the sum of the numbers in each matrix and the mean of these sums were calculated,

$-k$ was varied from 1 to the total image size.

For each $k$, a number which represented the mean variation of amount of luminophores in cells of size $k$ was obtained (unit: $\overline{\Delta Q} \mathrm{~cm}^{-1}$ ). This number increases linearly with respect to $k$. The slope, given by a linear regression, that quantifies the reworking is sizeindependent. In order to get a rate of reworking quantifying the mean movement of luminophores per surface unit and time $\left(\overline{\Delta Q} \mathrm{~cm}^{-2} t^{-1}\right)$, the slope was divided by the time 


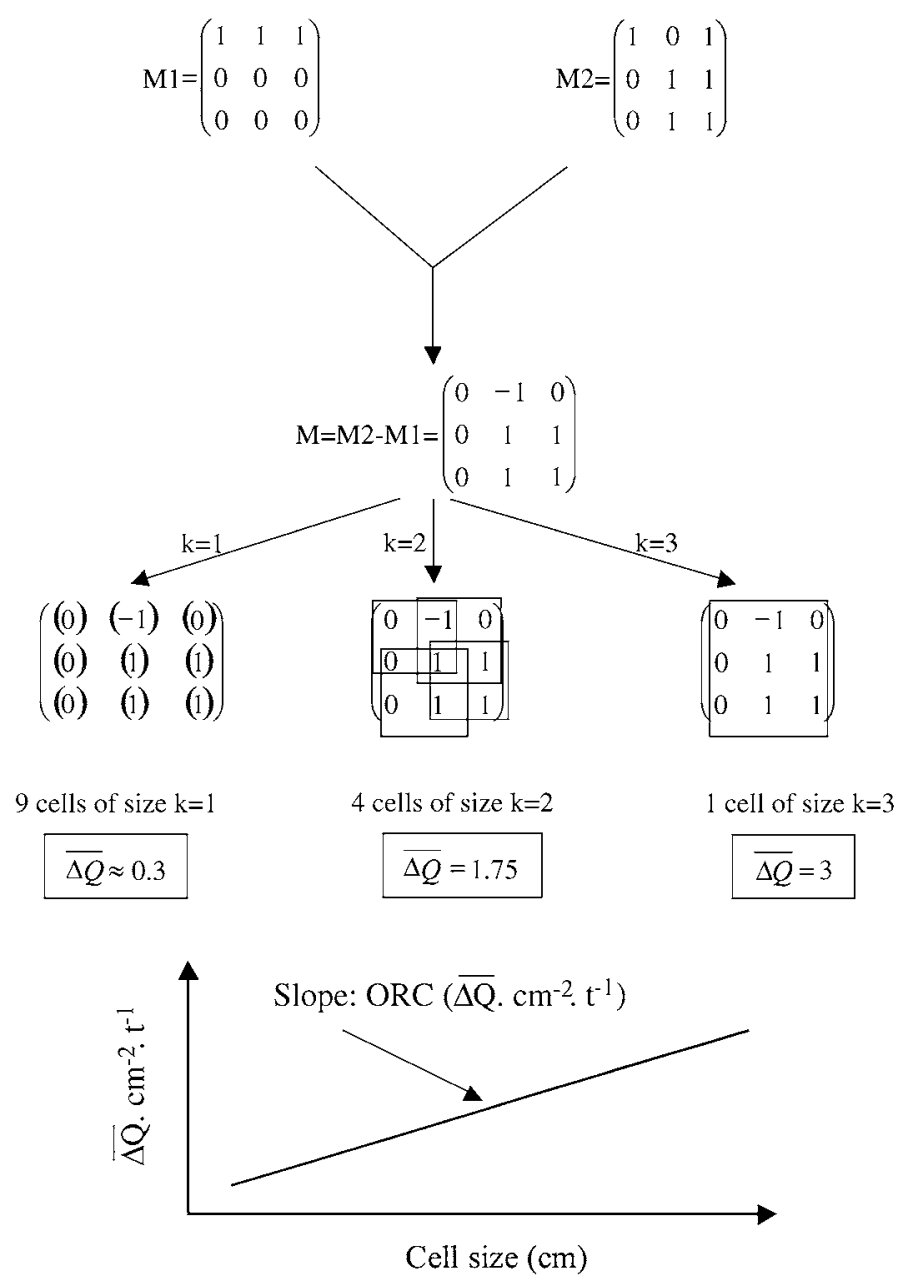

Fig. 2. Two-dimensional optical luminophore method. Schematic diagram based on a simple theoretical $3 \times 3$ matrix illustrating the calculation of the rate of reworking (named ORC, for optical reworking coefficient) corresponding to the mean movement of luminophores per surface unit and time (unit: $\overline{\Delta Q} \mathrm{~cm}^{-2} t^{-1}$ ).

interval corresponding to the initial and the final images. This rate was named ORC, for optical reworking coefficient (Fig. 2).

\section{Results}

Quantification of sediment reworking activities by model predictions on 1-D luminophore distribution patterns revealed comparable biodiffusion coefficients (average $D_{\mathrm{b}}: 14$ $\mathrm{cm}^{-2}$ year ${ }^{-1}$ ) and sediment depth of maximum particle burial (averaging $5.3 \mathrm{~cm}$ ) for the 
Gullmars Fjord stations (S1-S3; Table 1). The two Skagerrak stations (S4 and S5) were distinctly different from the Gullmars Fjord stations, and individually separated. Sediment reworking at the Norwegian Trench station (S4) was the lowest measured $\left(D_{\mathrm{b}}=5.4 \pm 0.6\right.$ $\mathrm{cm}^{-2}$ year $\left.^{-1} ; n=3\right)$, while calculated coefficient of biodiffusion was the highest measured

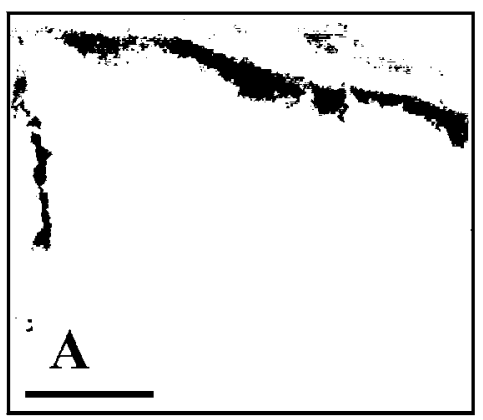

t: 0

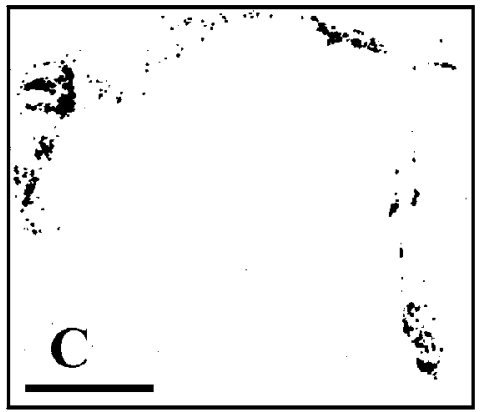

t: $21.15 \mathrm{~h}$

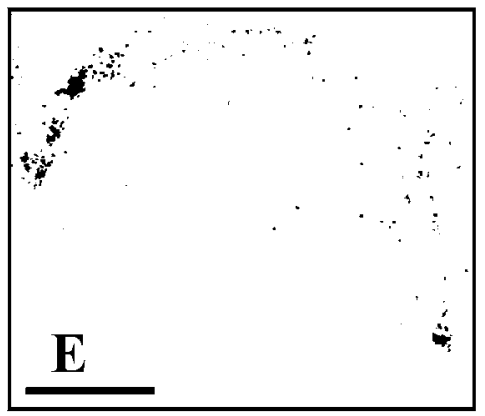

t: 30.00h

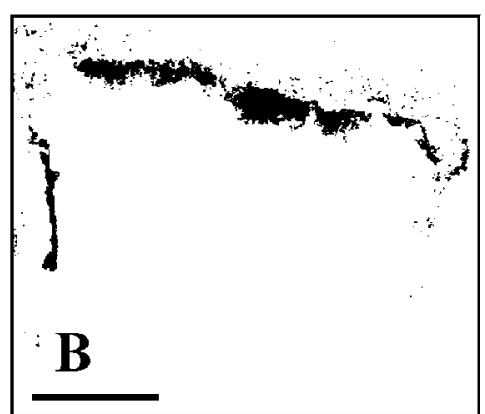

$\mathrm{t}: \mathbf{4 . 3 0 h}$

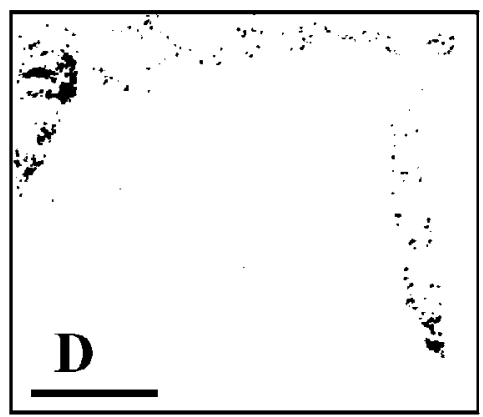

t: $24.30 h$

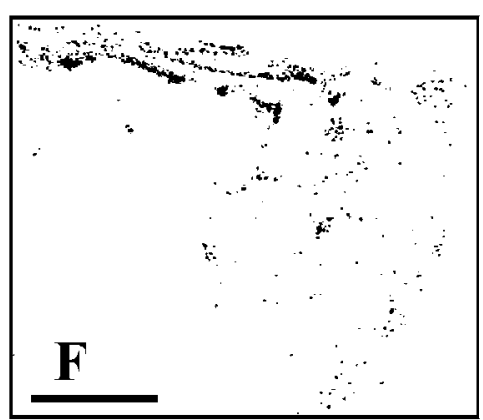

t: $38.45 h$

Fig. 3. A. filiformis (S5) and two-dimensional optical luminophore method. Sequence of images (i.e. A to F) showing the 2-D distribution of luminophores (visualized in white color) in the sediments with time. The time increment of each picture, since picture A, is indicated below the images. Scale bars $=1 \mathrm{~cm}$. To improve image visualization, binary but not grayscale images are presented. 
$\left(D_{\mathrm{b}}=35.5 \pm 3.7 \mathrm{~cm}^{-2}\right.$ year $\left.^{-1} ; n=3\right)$ at the Deep Trench (S5). At the latter station, fluorescent particles were found down to about $7 \mathrm{~cm}(6.7 \pm 3.7)$, while at $\mathrm{S} 4$ transport of particles was not significant below a sediment depth of $3 \mathrm{~cm}$ (Table 1).

Different sets of images were obtained with the optical system. As presented in Fig. 3, images sequences clearly showed rapid nonlocal transport of fluorescent particles initially deposited at the sediment surface.

Fig. 4 presents six examples, among the total set of 24, of optical reworking coefficients and associated regression coefficient $\left(R^{2}\right)$ calculated from Skagerrak Deep Trench station (S5) sediments. Values ranged from 13.95 to $44.53 \overline{\Delta Q} \mathrm{~cm}^{-2} \mathrm{~h}^{-1}$ with a mean ( \pm S.D.; $n=24)$ value of $27.42( \pm 9.01) \overline{\Delta Q} \mathrm{~cm}^{-2} \mathrm{~h}^{-1}$. Associated regression coefficients were never less than 0.95 .

Closer study of the images taken from the four faces of two cores showed that the calculated ORC was variable between the core faces, e.g. being up to 2.5 times higher in one face compared to another (core A; Table 2). However, the mean ORC calculated from results of the four faces of each core were almost similar: $26.85 \pm 10.45 \overline{\Delta Q}$
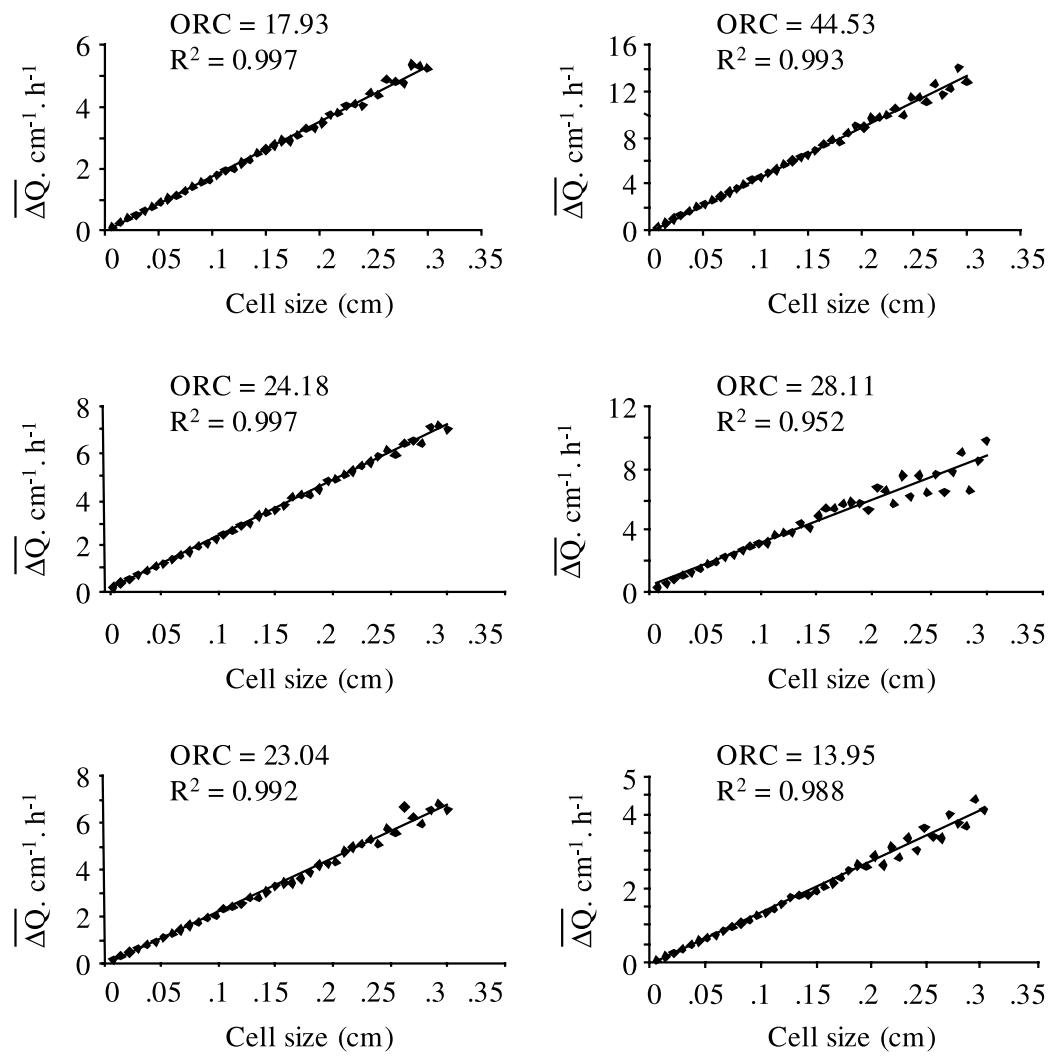

Fig. 4. A. filiformis (S5) and two-dimensional optical luminophore method. Six examples of calculation of the optical reworking coefficient (ORC; unit: $\overline{\Delta Q} \mathrm{~cm}^{-2} \mathrm{~h}^{-1}$ ) and associated regression coefficient $\left(R^{2}\right)$. 
Table 2

A. filiformis (S5) and two-dimensional optical luminophore method

\begin{tabular}{lllllll}
\hline Core A & & & & Core B & \\
\cline { 1 - 2 } \cline { 6 - 7 } & ORC & $R^{2}$ & & & ORC & $R^{2}$ \\
\hline Face 1 & 17.93 & 0.997 & & Face 1 & 24.48 & 0.995 \\
Face 2 & 44.53 & 0.993 & & Face 2 & 19.59 & 0.998 \\
Face 3 & 24.18 & 0.997 & & Face 3 & 13.95 & 0.988 \\
Face 4 & 20.75 & 0.95 & & Face 4 & 32.53 & 0.998 \\
Mean \pm S.D. & $26.85 \pm 10.45$ & & & Mean \pm S.D. & $22.63 \pm 6.82$ & \\
\hline
\end{tabular}

Optical reworking coefficients (ORC) and associated regression coefficient $\left(R^{2}\right)$ calculated with two images $(\Delta t$ : from 8 to $12 \mathrm{~h}$ ), for each face of two cores. For the method of ORC calculation, see text.

$\mathrm{cm}^{-2} \mathrm{~h}^{-1}( \pm$ S.D.; $n=4)$ and $22.63( \pm 6.82) \overline{\Delta Q} \mathrm{~cm}^{-2} \mathrm{~h}^{-1}$ for core A and B, respectively.

A long-term image sequence was performed from one face of the third core. Resulting optical reworking coefficients (ORC) were calculated either "from start", using the first image of the sequence as reference $(\Delta t$ between image $i$ and first image), or "step-by-step", using two consecutive images ( $\Delta t$ between image $i+1$ and image $i$ ). The "from start" calculation showed a stable ORC $\left(\sim 27 \overline{\Delta Q} \mathrm{~cm}^{-2} \mathrm{~h}^{-1}\right)$ with time, excepted a slight decrease down to $\sim 14.87 \overline{\Delta Q} \mathrm{~cm}^{-2} \mathrm{~h}^{-1}$ after $38.45 \mathrm{~h}$ of incubation (Fig. 5). On the other hand, the "step-by-step" calculation demonstrated only a general tendency of the ORC to be relatively more spread with time (from 23.04 to $\left.28.11 \overline{\Delta Q} \mathrm{~cm}^{-2} \mathrm{~h}^{-1}\right)$.

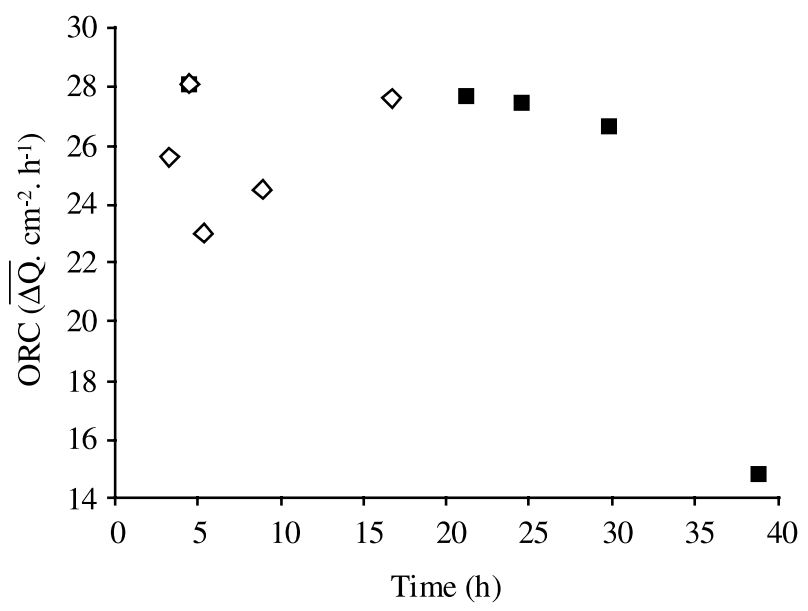

Fig. 5. A. filiformis (S5) and two-dimensional optical luminophore method. Optical reworking coefficient (ORC) vs. time, calculation either "from start", using the first image $(t=0)$ of the sequence as reference ( $\Delta t$ between image $i$ and first image; solid symbols), or "step-by-step", using two consecutive images ( $\Delta t$ between image $i+1$ and image $i$; open symbols). For the method of ORC calculation, see text. 


\section{Discussion}

The calculation of biodiffusion coefficient $\left(D_{\mathrm{b}}\right)$ using the "classical" method allowed us to confirm the very high impact on sediment reworking of the dominant dense $A$. filiformis population (Table 3) from a specific station of southeastern Deep Trench of Skagerrak (S5).

The images provided by the optical system have made possible visualization of particle displacements inside the sedimentary column due to the activities of this population. It was anticipated based on results from the classical luminophore method (see above) that bioturbation by this species was of the biodiffusor functional type (François et al., 2001). Instead, it appeared that particles were displaced in a nonlocal mixing pattern sensu Boudreau (1986), i.e. material is transported between points that are not adjacent to each other. Nevertheless, a general trend leading to a homogenization inside the sedimentary column with time was suspected. Indeed, this homogenization pattern is a common trend with time whatever the particular mode of sediment mixing, as illustrated by other specific models (not based on Berner's equation; e.g. Boudreau et al., 2001). Those localized movements could be easily linked to the construction of disc chambers and maintenance of burrows by the organisms, as very recently visualized and quantified by Solan and Kennedy (2002).

Our goal was not only to get some images of the 2-D repartition of luminophores in the sediments but also to use this information to quantify sediment reworking by infaunal activities. By analogy with the "classical" luminophore method, the calculated amount of tracer was projected in horizontal layers to get a 1-D repartition. Using the obtained profiles that were of diffusive-like shape, biodiffusion coefficients $\left(D_{\mathrm{b}}\right)$ were calculated using the Cochran model (1985). However, extremely high $D_{\mathrm{b}}$ were then obtained, e.g. $274 \mathrm{~cm}^{-2}$ year $^{-1}$ (data not shown). This was explained by (i) the reduced information contained in the 2-D compared to the 3-D sampling (classical method), and (ii) initial conditions were not appropriate for the Cochran model, i.e. at the start of experiment, $t=0$, all the tracers have to be homogeneously located at the sediment surface $\left(C(0 ; 0)=C_{0}\right.$; $C(z ; 0)=0 ; z$ : depth).

Obviously, while looking at our images, these requested initial conditions were not fulfilled even when using a 1-cm-thick layer virtual slicing for calculation (e.g. as shown in Fig. 3).

Table 3

Station S5 abundance per $\mathrm{m}^{2}$ of the dominant species in the sediments sampled in August 1999 (mean \pm S.D., $n=3)$

\begin{tabular}{lr}
\hline Species & ind. $\mathrm{m}^{-2}$ \\
\hline Amphiura filiformis & $2030 \pm 410$ \\
Heteromastus filiformis & $210 \pm 12$ \\
Abra nitida & $121 \pm 53$ \\
Maldane sarsi & $92 \pm 75$ \\
Myriochele oculata & $20 \pm 15$ \\
\hline
\end{tabular}

In May 2001, $4.3 \pm 0.5\left(2708 \pm 295\right.$ ind. $\left.\mathrm{m}^{-2}\right)$ A. filiformis individuals were present in the studied cores. 
Then, in order to use our precise two-dimensional data, we developed a new particle reworking quantification (ORC, optical reworking coefficient; $\overline{\Delta Q} \mathrm{~cm}^{-2} \mathrm{~h}^{-1}$ ) expressing the total variation of luminophores per surface and time units.

When taking into account the four faces of the rectangular sampling cores, the new 2-D optical method and calculation of the ORC allowed us to efficiently compare the sediment reworking occurring in different samples from the same location. Moreover, no specific initial conditions have to be satisfied in order to calculate the ORC, the coefficient being independent of both the tracer repartition (with potential limitation limit, cf. below) and the size of the quantification cells used (as a slope of a linear relationships). Furthermore, the ORC coefficient appears to be very flexible in use being independent of the time interval between the images. This, however, may have some limitation due to the actual experimental setup that we used (small surface cores), which may have induced a change in the organism behavior inside the sediments after a certain period of incubation. Also, the homogenization of the luminophores repartition with time could reduce the visualization of the reworking process while increasing the quantity of undetected events, i.e. the more homogeneous is the luminophore repartition, the more frequent is the occurrence of an exchange between two fluorescent tracers.

Since the 2-D approach cannot provide biodiffusion coefficients, it cannot replace the 1-D approach, but should rather be regarded as a supplementary technique to study the sediment bio-reworking. The classical method, which is destructive, quantifies $\left(D_{\mathrm{b}}\right)$ the global movements of particles inside the sedimentary column but cannot be used for small time and spatial scale measurements. On the other hand, the new optical nondestructive technique allows the quantification of the 2-D particle displacements (ORC) based on high spatial and temporal resolutions. Such high resolution is required to precisely study infauna behavioral ecology as it has been done here with an A. filiformis population. Moreover, contrary to the biodiffusion coefficient, the ORC is not related to a specific type of particle movements. Physically, it corresponds to a quantity of particle displaced per surface unit and per time unit. In the frame of bioturbation studies, it can be then useful to compare sediment reworking between locations whatever the bioturbating organisms (functional groups) or communities involved, whereas $D_{\mathrm{b}}$ can be only estimated from diffusive-like particle transport.

The next step in the development of this new method will be to test it on several other types of sediments with other monospecific faunal communities (functional groups) and then to more complex multispecific communities. Based on such studies, the linkage between the 1-D $\left(D_{\mathrm{b}}\right)$ and the 2-D (ORC) methods should be, if it exists, established. Moreover, this 2-D optical quantification of sediment reworking is very promising while able to provide a important basis information about the bioturbation process when combined with the recently developments of solute 2-D distribution quantification.

\section{Acknowledgements}

We would like to thank Kristina Sundbäck (Marine Botany, Göteborg University, Sweden) who hosted us to perform the luminophore counts on her stereo UV microscope, and Eric Gilbert (BCEOM, Montpellier, France) for his advice on image analysis. Thanks 
are also due to the crews of N/V Arne Tiselius for their help on the field, to the Benthic Dynamics Conference 2002 participants, especially Yoko Furukawa, Joe Germano, Robert Kennedy and Martin Solan, for their positive feedback, and to two anonymous reviewers for their constructive comments. This work was supported by a mise à disposition fellowships from the Centre National de la Recherche Scientifique to Franck Gilbert. Financial support to Stefan Hulth was obtained from the Swedish Natural Science Research Council (VR), the Swedish Engineering Foundation (CF), the Technology Link Foundation in Göteborg (TBSG) and the Foundation for Strategic Environmental Research (MISTRA). Nereis Park contribution no. 003. [RW]

\section{References}

Aller, R.C., 1982. The effects of macrobenthos on chemical properties of marine sediment and overlying water In: McCall, P.L., Tevesz, M.J.S. (Eds.), Animal-Sediment Relations. Plenum, New York, pp. 53-102.

Aller, R.C., 1994. Bioturbation and remineralization of sedimentary organic matter: effects of redox oscillation. Chem. Geol. 114, 331-345.

Barnett, P.R.O., Watson, J., Connelly, D.C., 1984. A multiple corer for taking virtually undisturbed samples from shelf, bathyal and abyssal sediments. Oceanol. Acta 7, 399-408.

Berg, P., Rysgaard, S., Funch, P., Sejr, M.K., 2001. Effects of bioturbation on solutes and solids in marine sediments. Aquat. Microb. Ecol. 26, 81-94.

Berkenbusch, K., Ashley, A.R., 1999. Factors influencing sediment turnover by the burrowing ghost shrimp Callianassa filholi (Decapoda: Thalassinidea). J. Exp. Mar. Biol. Ecol. 238, 283-292.

Berner, R.A., 1980. Early Diagenesis: A Theoretical Approach. University Press, Princeton. 241 pp.

Boudreau, B.P., 1986. Mathematics of tracer mixing in sediments: II. Nonlocal mixing and biological conveyorbelt phenomena. Am. J. Sci. 286, 199-238.

Boudreau, B.P., 1997. Diagenetic Models and their Implementation. Springer-Verlag, Berlin. 414 pp.

Boudreau, B.P., Choi, J., Meysman, F., François-Carcaillet, F., 2001. Diffusion in a lattice-automation model of bioturbation by small deposit feeders. J. Mar. Res. 59, 749-768.

Buchanan, J.B., 1964. A comparative study of some features of the biology of Amphiura filiformis and Amphiura chiajei (Ophiurroidea) considered in relation to their distribution. J. Mar. Biol. Assoc. UK 44, 565-576.

Cochran, J.K., 1985. Particle mixing rates in sediments of the eastern equatorial Pacific: evidence from ${ }^{210} \mathrm{~Pb}$, ${ }^{239},{ }^{240} \mathrm{Pu}$ and ${ }^{137} \mathrm{Cs}$ distribution at MANOP sites. Geochim. Cosmochim. Acta 49, 1195-1210.

François, F., Poggiale, J.-C., Durbec, J.-P., Stora, G., 2001. A new model of bioturbation for a functional approach to sediment reworking resulting from macrobenthic communities. In: Aller, J.Y., Woodin, S.A., Aller, R.C. (Eds.), Organism-Sediment Interactions. The Belle W. Baruch Library in Marine Science, vol. 21. University of South Carolina, Columbia, pp. 73-86.

Gérino, M., 1990. The effects of bioturbation on particle redistribution in Mediterranean coastal sediment Preliminary results. Hydrobiologia 207, 251-258.

Gérino, M., Aller, R.C., Lee, C., Cochran, J.K., Aller, J.Y., Green, M.A., Hirschberg, D., 1998. Comparison of different tracers and methods used to quantify bioturbation during a spring bloom: 234-thorium, luminophores and chlorophyll- $a$. Estuar. Coast. Mar. Sci. 46, 531-548.

Gilbert, F., Stora, G., Bertrand, J.-C., 1996. In situ bioturbation and hydrocarbon fate in an experimental contaminated Mediterranean coastal ecosystem. Chemosphere 33, 1449-1458.

Glud, R.N., Ramsing, N.B., Gundersen, J.K., Klimant, I., 1996. Planar optrodes: a new tool for fine scale measurements of two-dimensional $\mathrm{O}_{2}$ distribution in benthic communities. Mar. Ecol., Prog. Ser. 140, $217-226$.

Glud, R.N., Tengberg, A., Kühl, M., Hall, P.O.J., Klimant, I., Holst, G., 2001. An in situ instrument for planar O optode measurements at benthic interfaces. Limnol. Oceanogr. 46, 2073-2080.

Hulth, S., Aller, R.C., Engström, P., Selander, E., 2002. A pH plate fluorosensor (optode) for early diagenetic studies of marine sediments. Limnol. Oceanogr. 47, 212-2220. 
Hulthe, G., Hulth, S., Hall, P.O., 1998. Effect of oxygen on degradation rate of refractory and labile organic matter in continental margin sediments. Geochim. Cosmochim. Acta 62, 1319-1328.

Mahaut, M.L., Graf, G., 1987. A luminophore tracer technique for bioturbation studies. Oceanol. Acta 10 , $323-328$.

Rhoads, D.C., 1974. Organism-sediment relations on the muddy sea floor. Oceanogr. Mar. Biol. Ann. Rev. 12 , $263-300$.

Rosenberg, R., 1995. Benthic marine fauna structured by hydrodynamic processes and food availability. Neth. J. Sea Res. 34, 303-317.

Rosenberg, R., Nilsson, H.C., Hollertz, K., Hellman, B., 1997. Density-dependent migration in an Amphiura filiformis (Amphiuridae, Echinodermata) infaunal population. Mar. Ecol., Prog. Ser. 159, 121-131.

Soetaert, K., Herman, P.M.J., Middelburg, J.J., 1996. A model of early diagenetic processes from the shelf to abyssal depths. Geochim. Cosmochim. Acta 60, 1019-1040.

Solan, M., Kennedy, R., 2002. Observation and quantification of in situ animal-sediment relations using timelapse sediment profile imagery (t-SPI). Mar. Ecol., Prog. Ser. 228, 179-191.

Sun, M.-Y., Aller, R.C., Lee, C., Wakeham, S.G., 1999. Enhanced degradation of algal lipids by benthic macrofaunal activity: effect of Yoldia limatula. J. Mar. Res. 57, 775-804. 